\title{
SCOUR INVESTIGATION AROUND SINGLE AND TWO PIERS SIDEBYSIDE ARRANGEMENT
}

\author{
Zulhilmi Ismail $^{1}$, Mazlin Jumain², FaridahJaafar Sidek ${ }^{3}$, Ahmad KhairiAbd Wahab ${ }^{4}$, Zulkiflee Ibrahim $^{5}$, \\ MohamadHidayat Jamal ${ }^{6}$ \\ ${ }^{1,3,4,5,6}$ Senior Lecturer, Faculty of Civil Engineering, Universiti Teknologi Malaysia, Johor, Malaysia, zulhilmi@utm.my, \\ faridah@utm.my,akhairi@utm.my,zulkfe@utm.my,mhidayat@utm.my \\ ${ }^{2}$ Research Student, Faculty of Civil Engineering, Universiti Teknologi Malaysia, Johor, Malaysia, \\ mazlinjumain@gmail.com
}

\begin{abstract}
Laboratory experiments concerning scour development around single and two piers side by side arrangement have been conducted in order to provide a comparison of scour depths and patterns. The experiments are carried out under unidirectional currents of clearwater scour conditions. A variety of conditions including different flow depths, pier diameters and pier spacing are considered to have significant influence on the development of the potential scour hole. The research on local scour around single and two piers side by side arrangement are studied by using a $15.24 \mathrm{~m}$ long, $0.46 \mathrm{~m}$ wide and $0.4 \mathrm{~m}$ deep flume in the Hydraulics and Hydrology Laboratory, Universiti Teknologi Malaysia (UTM).Experimental results describing the scour-hole depths and patterns are discussed. The results show that the magnitude and extent of the scour depth depends directly on pier size, pier spacing and flow condition. Piers, which are larger in diameter, produced greater scour depth. It also shows that by increasing the pier spacing, the scour depth around two piers decreases and closes to values of single pier. The two piers act as an obstruction which disturbed the flow field and caused large turbulence levels to be generated. Thereby, a further increase in the scouring velocity is produced giving relatively higher scour depth values. The prime factors governing the local scouring process associated with piers are pier spacing, horseshoe vortex, reinforcing and sheltering. The results show that good agreement with previous study where the down flow causes of increased scour for a single pier case. Meanwhile, the horseshoe vortex appears to be the main cause of scour in the case of two piers side by side arrangement.
\end{abstract}

Keywords: Scour depth, Flow pattern, Single pier, Side by side piers, Pier spacing, Horseshoe vortex

\section{INTRODUCTION}

Scouring is an important phenomenon in river mechanics. It generally takes place in alluvial channels and around manmade structures such as bridge piers, spur dikes and embankments. When an alluvial stream is partially obstructed by a bridge pier, the flow pattern in the channel around the pier is significantly changed. The pier produces an adverse pressure gradient just upstream of the pier. The boundary layer upstream of the pier undergoes a three-dimensional separation. The shear stress distribution around the pier is drastically changed due to the formation of a horseshoe vortex, resulting in scour around the pier which, in turn, changes the flow pattern [1].

Pier scour is the greatest causes of bridge failures. Due to extreme scour around piers, scouring has long been acknowledged as a severe hazard to the performance of bridge piers. This phenomenon has motivated many investigators to explore the causes of scouring and to predict maximum scour depth at bridge piers $[2,3,4]$. According to Cheremisinoff[5], the interaction between the flow around a bridge pier and the erodible bed surrounding it is very complex. Mubeen[6] also stated that the presence of group of bridge piers can generate a complex in the hydrodynamic characteristics of the flow field near the piers and lead to the occurrence and development of a scour process. Flow observations reveal that a complex ordered flow pattern (Fig -1) occurs even in a case of simple geometry hydraulic structure [7]. Therefore, a comprehensive understanding of the complex flow field and erosion mechanisms can provide a way out of this problem.

Ahmed and Rajaratnam[8], Ettema et al. [9], Thameret al. [10], Kirkilet al. [11], Padmini and Asis[12], Yasser and Ahmed[13], Guneyet al. [14] andElsebaie[15] have made some studies and gave information for a better understanding of the flow pattern and turbulent flow around single pier. There are a large number of studies around pier groups and complex piers that focused on the prediction of maximum scour depth [16, 17, 18,19] and the effect of the pier spacing on the scour depth [20]. Several laboratory studies have been carried out to investigate the relationship between pier spacing 
and maximum scour depth around two piers side by side arrangement $[21,22,23$. 24]. Fig -2 shows a sketch of the flow pattern and local scour around side by side piers arrangement. The mechanisms which affect scour pattern around side-by-side piers, includes: reinforcing effect, sheltering effect, shed vortex and compressed horseshoe vortex [25].

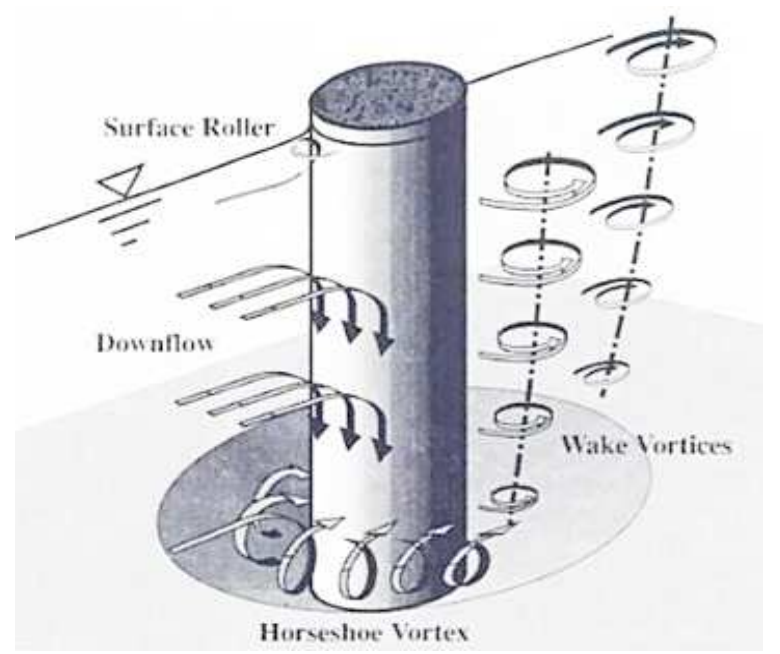

Fig -1: Flow pattern around cylindrical pier with a developed scour hole

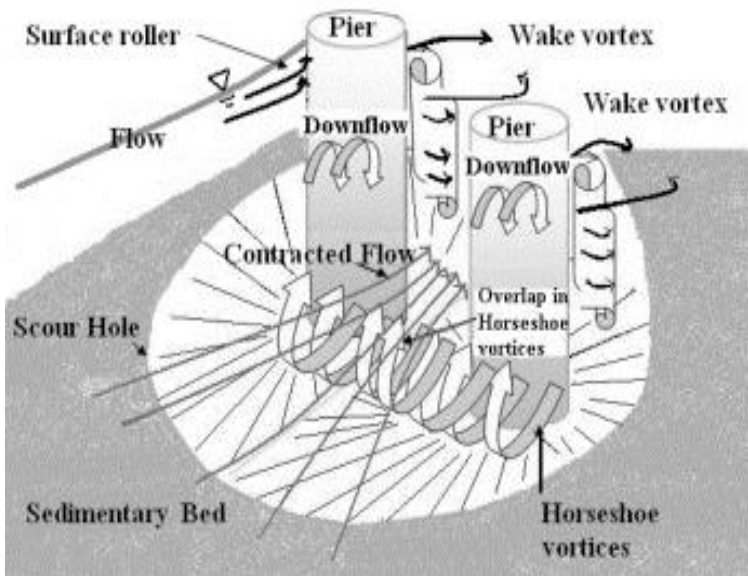

Fig -2: Flow pattern and local scour around side by side piers arrangement

Experimental investigations on the scour around single and two piers side by side arrangement have been undertaken. The main objective of this study is to carry out a detailed experimental investigation of the influence of flow on scour development around two piers side by side arrangement. Extensive laboratory have been conducted to study the scourhole patterns in the vicinity of piers. As a reference study, the experiments have also been conducted around a single pier.
The study is focused on the influence of flow depth, pier diameter and pier spacing on the development of the scour hole and pattern.

\section{EXPERIMENTAL SETUP}

A series of experiments is carried out for single and two piers side by side arrangement in a flume at the Hydraulics Laboratory, Faculty of Civil Engineering, Universiti Teknologi Malaysia (UTM). The dimensions of the flume are $15.24 \mathrm{~m}$ long, $0.46 \mathrm{~m}$ wide and $0.4 \mathrm{~m}$ deep. For the experimental works, a portion of recess $4.50 \mathrm{~m}$ long, $0.46 \mathrm{~m}$ wide and $0.15 \mathrm{~m}$ deep are provided in the middle section of the flume to serve as the working section. The slope of the flume for all tests is fixed to 0.0006 and uniform graded sand with a $\mathrm{d}_{50}$ of $0.3 \mathrm{~mm}$ is used as its bed material.

In order to investigate the effect of pier diameters on the scour characteristics, sizes of $32 \mathrm{~mm}, 42 \mathrm{~mm}$ and $60 \mathrm{~mm}$ pier diameters are selected. The bottom of the pier model is welded to a square base plate of $100 \mathrm{~mm}$ dimension and $5 \mathrm{~mm}$ thickness. The base is placed on the flume bottom. The pier is placed vertically at the centerline of the test section. Fig-3 and Fig -4 show the schematic diagram of pier configurations tested in the flume.

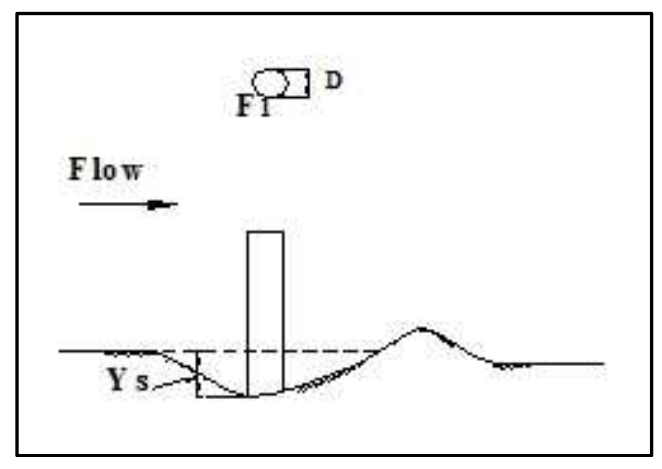

Fig -3: Single pier

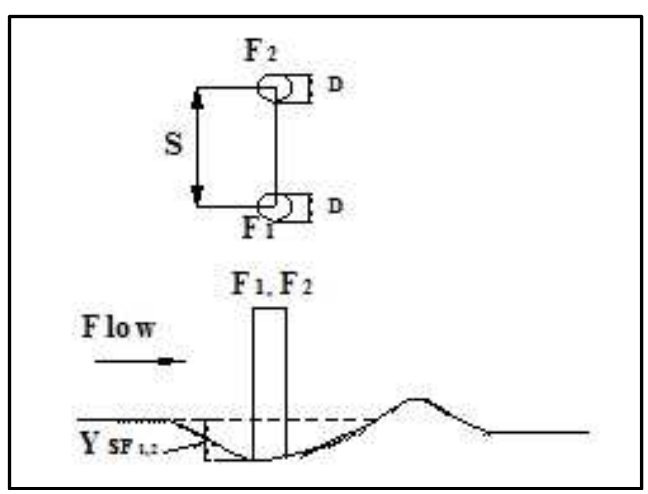

Fig -4: Two piers with side by side arrangement 
For these experiments, the water depths are measured by mean of a point gauge mounted on the carriage which could be moved along the rails attached to the top of the flume side walls. The point gauge could be read accurate to nearest of 0.1 $\mathrm{mm}$. In order to investigate the effect of flow depths on the scour characteristics, two different water depths $\left(\mathrm{Y}_{0}=160\right.$ $\mathrm{mm}, 190 \mathrm{~mm}$ and $230 \mathrm{~mm}$ ) are adopted in the study. The scour-hole geometry is also determined using the point gauge at the end of each run. Longitudinal and transverse coordinates of the point gauge measurements are obtained using scales marked on the instrument carriage as well as the positioning scales at the rails of the flume.

Flow velocities are measured using Acoustic Doppler Velocimeter(ADV). With the use of appropriate software, the values of the velocity are gathered and stored in computer. In this experiment, a 3-D down looking probe is used to plot the velocity profiles which relate to unidirectional flow distribution along a channel. Velocity data are collected at the upstream, middle and downstream end of the piers to determine the main velocity components affecting the scour depth around the piers. The average flow velocities of 232 $\mathrm{mm} / \mathrm{s}, 206 \mathrm{~mm} / \mathrm{s}$ and $175 \mathrm{~mm} / \mathrm{s}$ are measured for three flow depths $\left(\mathrm{Y}_{0}\right)$ namely $160 \mathrm{~mm}, 190 \mathrm{~mm}$ and $230 \mathrm{~mm}$, respectively.

\section{RESULTS AND DISCUSSION}

The effects of flow depth, pier diameter and pier spacing on the scour development around single and two piers side by side arrangement are studied in the laboratory. The contour plots show the scour depth characteristics in $\mathrm{mm}$. Negative contour values indicate erosion while positive values indicate deposition. The plots have been produced by using SURFER 16 software which is a computer graphics system for displaying data in the form of contoured plots. Experimental results describing the scour patterns around a single pier are discussed in Section 3.1. For scour patterns around two piers side by side arrangement results are described in Section 3.2. This is followed by a discussion on the effect of flow depth, pier diameter and pier spacing on the scour patterns, as described in Sections 3.2.1, 3.2.2 and 3.2.3 respectively.

\subsection{Scour Patterns around a Single Pier}

Local scouring around a single bridge pier has been attempts firstly investigated to generate basic observation of scour patterns and serves as a control. Figures 3, 4 and 5 illustrate plots of scour patterns produced by three different pier diameters $(D=32 \mathrm{~mm}, 42 \mathrm{~mm}$ and $60 \mathrm{~mm})$ and two different water depths $(Y 0=160 \mathrm{~mm}$ and $190 \mathrm{~mm})$. The formation of single scour holes immediately around the pier is observed.

Fig-5shows that the formation of one big scour hole immediately around the pier is seen. The maximum scour depth around the pier is $30 \mathrm{~mm}$. Meanwhile, the maximum deposition is $15 \mathrm{~mm}$ which only occurs at distance of 400 to $500 \mathrm{~mm}$ along the channel. Similar scour pattern is observed in Fig-6. Due to increases of pier diameter from $32 \mathrm{~mm}$ to 42 $\mathrm{mm}$, the formation of scour hole around pier is seen slightly greater than the previous scour hole. However, the maximum scour hole is also $30 \mathrm{~mm}$. The maximum deposition is $20 \mathrm{~mm}$. Fig-7 also shows that the formation of scour hole immediately occurs around the pier. The scour hole is slightly greater and deeper than other pier sizes. The maximum scour depth around the pier is $45 \mathrm{~mm}$. Meanwhile, the maximum deposition is $25 \mathrm{~mm}$. It can be concluded that the extent of the scour hole was slightly greater and deeper in the case of bigger pier sizes and shallower flow depths due to the increased flow velocity.

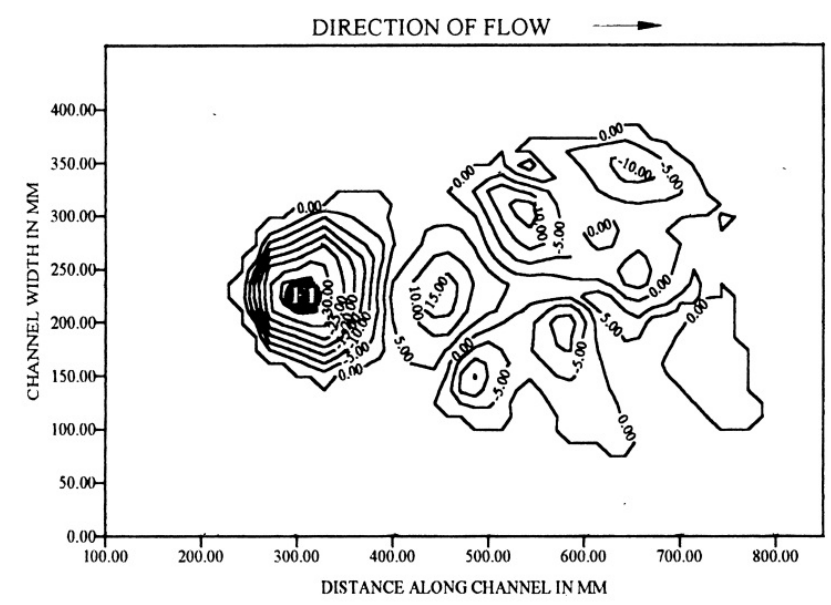

Fig -5: Scour hole due to unidirectional flow for a single pier $(\mathrm{D}=32 \mathrm{~mm}$ and $\mathrm{Y0}=160 \mathrm{~mm})$

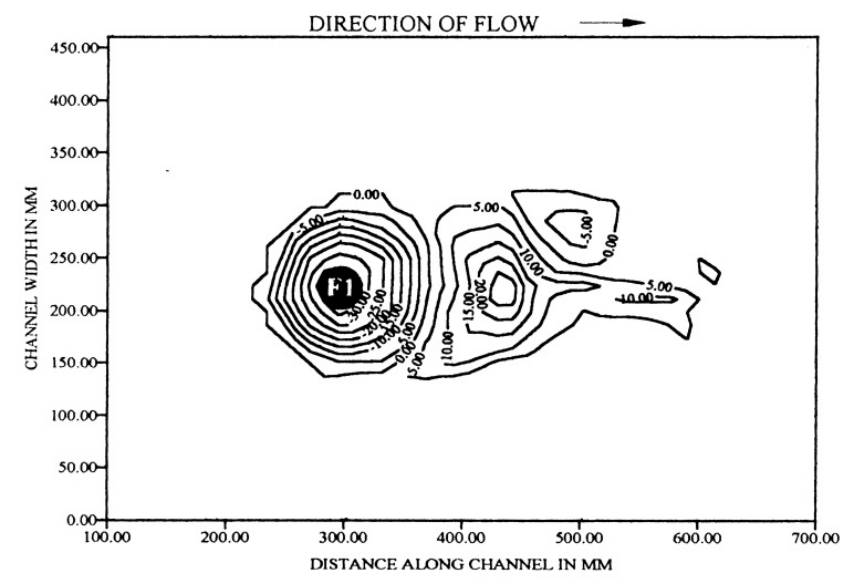

Fig -6: Scour hole due to unidirectional flow for a single pier $(\mathrm{D}=42 \mathrm{~mm}$ and $\mathrm{Y0}=190 \mathrm{~mm})$ 


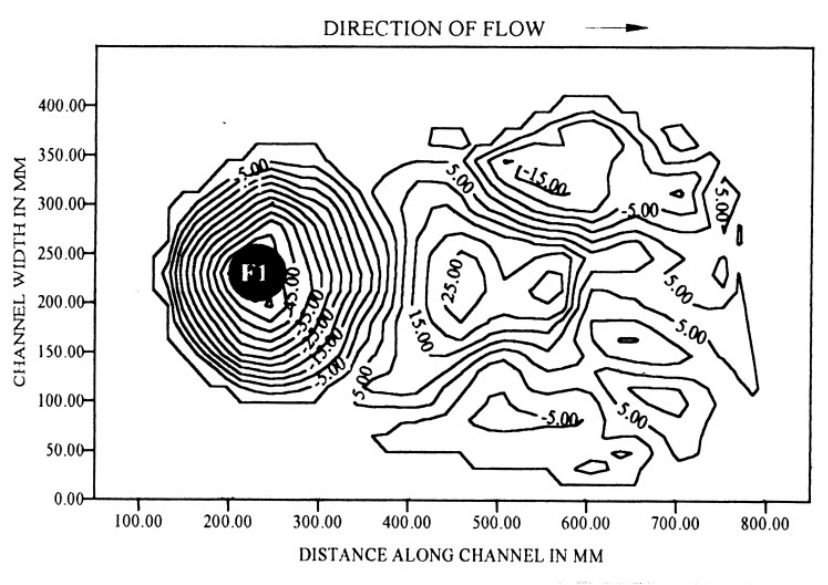

Fig -7: Scour hole due to unidirectional flow for a single pier $(\mathrm{D}=60 \mathrm{~mm}$ and $\mathrm{Y0}=160 \mathrm{~mm})$

\subsection{Scour Patterns around Two Piers Side by Side}

\section{Arrangement}

Local scour associated with two piers in side by side arrangement is discussed in this section. Results from six different measurements have been described to show the characteristics of local scour depth formation associated with the effect of flow depth $\left(\mathrm{Y}_{0}\right)$, pier diameter (D) and pier spacing $(\mathrm{S})$. The plots of the scour-hole contours represent the scour depth formation in $\mathrm{mm}$.

\subsubsection{Effect of Flow Depth}

Fig-8andFig -9 represent the scour and deposition patterns produced by two piers of similar sizes $(\mathrm{D}=60 \mathrm{~mm})$ and pier spacing $(\mathrm{S}=2 \mathrm{D})$ which are placed at two different flow depths $\left(\mathrm{Y}_{0}=160 \mathrm{~mm}\right.$ and $230 \mathrm{~mm}$ )in a side by side arrangement. In both cases, the formation of two separate scour holes immediately around the first and second front piers is seen. Similar scour patterns are observed.

Fig- 8 shows the maximum scour depth around the piers is 60 $\mathrm{mm}$. Meanwhile, the maximum scour depth for Fig-9 is 30 $\mathrm{mm}$. Thus, the extent of the scour hole is slightly greater and deeper in the case when the piers are placed under a shallower flow depth which produced a higher velocity. Since both the first front and second front piers are equally exposed to the flow, the scour depths in front of them are identical.

Fig- 8 also shows the maximum scour depth around the two piers side by side arrangement is about $35 \%$ higher than the single pier. When the piers are placed in deeper flow depth as shown in Fig-9, the maximum scour depth decreased about $50 \%$ compared to shallower flow depth condition. It occurs due to the flow velocity decreases as the flow depth increases. In addition, the two piers act as an obstruction which disturbed the flow field and caused large turbulence levels to be generated. Thus, a further increase in the scouring velocity is produced giving relatively higher scour depth values [25].

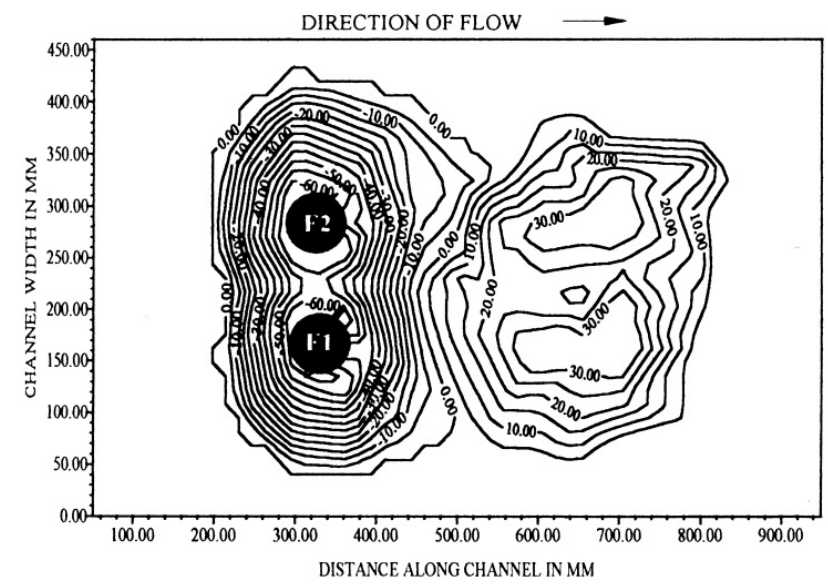

Fig -8: Scour hole due to unidirectional flow for two piers in a side by side arrangement $\left(\mathrm{D}=60 \mathrm{~mm}, \mathrm{Y}_{0}=160 \mathrm{~mm}\right.$ and S/D $=2)$

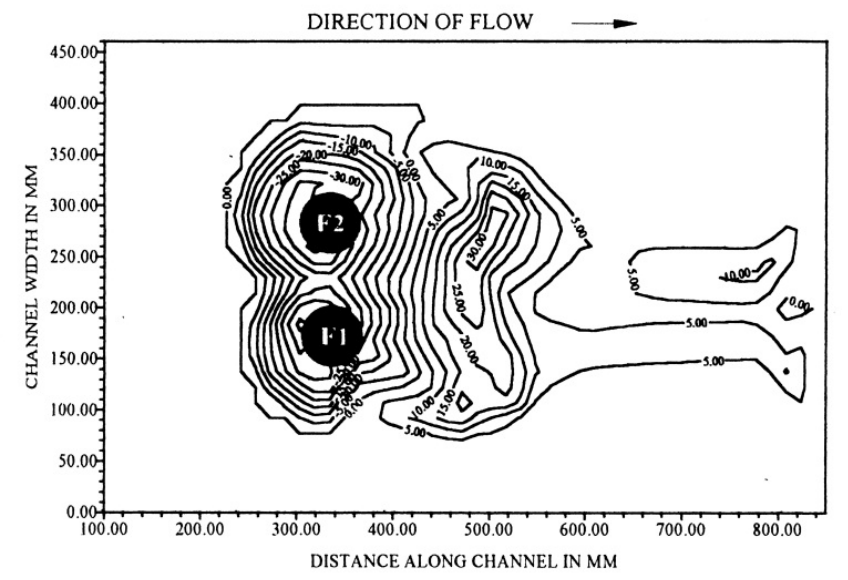

Fig -9: Scour hole due to unidirectional flow for two piers in a side by side arrangement $\left(D=60 \mathrm{~mm}, \mathrm{Y}_{0}=230 \mathrm{~mm}\right.$ and $\mathrm{S} / \mathrm{D}$ $=2$ )

\subsubsection{Effect of Pier Diameter}

Fig-10 and Fig -11 indicate that the bed contour plots of scour pattern and maximum scour depth for different pier sizes $(\mathrm{D}=$ $32 \mathrm{~mm}$ and $42 \mathrm{~mm})$ at similar pier spacing $(\mathrm{S}=1.5 \mathrm{D})$ and flow depth $\left(\mathrm{Y}_{0}=160 \mathrm{~mm}\right)$. In this case, a single scour hole was observed. The observed scour patterns formation for both piers are similar. This is because of both the first and second front piers are equally exposed to the flow causing the scour depths in front of them to be identical. A slightly different scour pattern is produced when two different pier sizes are 
used. It is also revealed that by increasing the pier sizes, the scour depth around side by side piers also increases.

Fig-10 shows the maximum scour depth around the piers is 35 $\mathrm{mm}$. Meanwhile, the maximum scour depth for Fig-11 is 55 $\mathrm{mm}$. From there, it is found that the maximum scour depth for the piers size of $42 \mathrm{~mm}$ is about $60 \%$ higher than the piers size of $32 \mathrm{~mm}$ condition. The flow between two piers with greater size is accelerated into scour hole so that it influences the vertical and deflections of the flow around and especially between them [21]. Thus, a further increase in the pier size is produced giving relatively higher scour depth values.

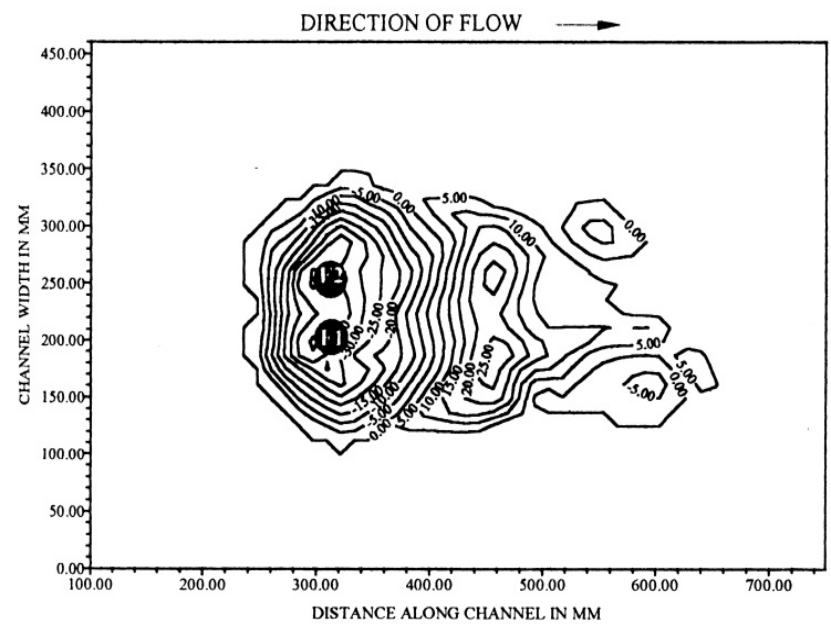

Fig -10: Scour hole due to unidirectional flow for two piers in a side by side arrangement $\left(\mathrm{D}=32 \mathrm{~mm}, \mathrm{Y}_{0}=160 \mathrm{~mm}\right.$ and $\mathrm{S} / \mathrm{D}=1.5)$

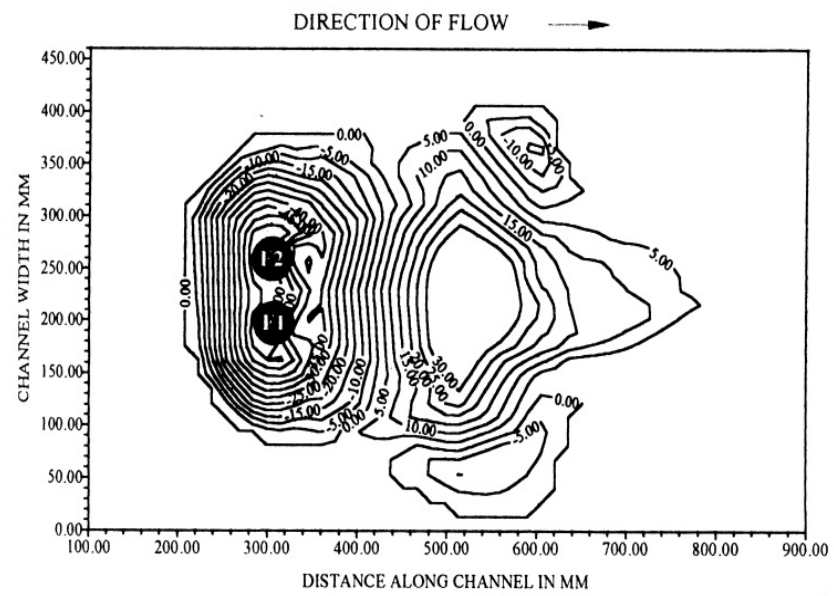

Fig -11: Scour hole due to unidirectional flow for two piers in a side by side arrangement $\left(\mathrm{D}=42 \mathrm{~mm}, \mathrm{Y}_{0}=160 \mathrm{~mm}\right.$ and $\mathrm{S} / \mathrm{D}=1.5)$

\subsubsection{Effect of Pier Spacing}

Fig-12 and Fig-13 illustrate the scour patterns and maximum scour depths for two different pier spacing $(S=2 D$ and $5 \mathrm{D})$ for similar pier diameter $(\mathrm{D}=32 \mathrm{~mm})$ and similar flow depth $\left(\mathrm{Y}_{0}=160 \mathrm{~mm}\right)$. From these figures, it is observed that a single scour depth is seen at 2D pier spacing and two isolated scour depths are observed at 5D pier spacing. A significantly different scour pattern is observed for larger pier spacing compared to that of the smaller pier spacing. At $S=5 \mathrm{D}$, each pier will have its own scour hole with no scour holes overlapping as in the case of $2 \mathrm{D}$ pier spacing.

The maximum scour depth around the piers for Fig-12 is 50 mm. Meanwhile, the maximum scour depth for Fig-13 is 35 $\mathrm{mm}$. It is found that the maximum scour depth for greater the pier spacing, 2D is about $45 \%$ higher than the pier spacing of 5D condition. When the piers placed close together, the interference between the horseshoe vortices caused the deepest scour depth in front of the piers. The results also show that by increasing the space between piers, the interference between the horseshoe vortices decreases [22, 26]. By increasing the pier spacing, the scour depths around the piers decreases and similar patterns observed as single pier. It occurs due to the lower magnitude of down flow and vertical turbulence intensity as well as turbulence kinetic energy between the larger spacing piers.

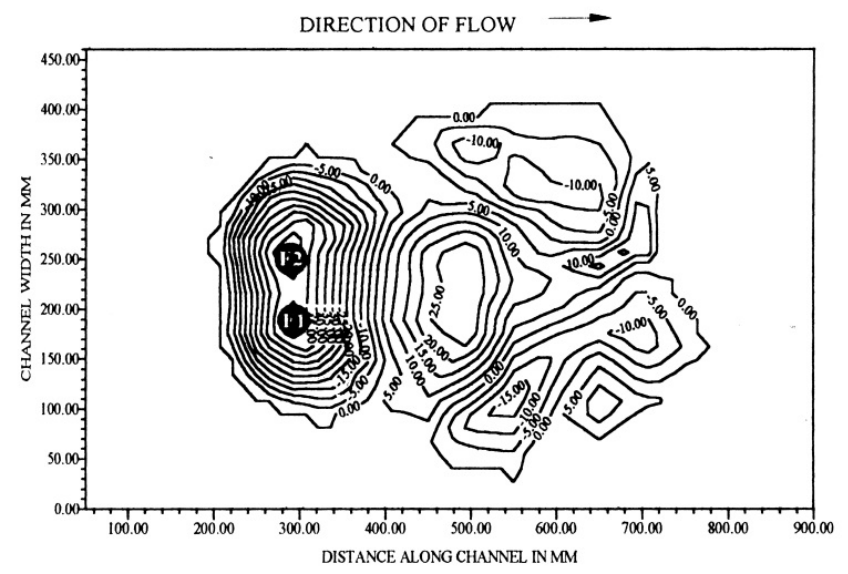

Fig -12: Scour hole due to unidirectional flow for two piers in a side by side arrangement $\left(D=32 \mathrm{~mm}, \mathrm{Y}_{0}=160 \mathrm{~mm}\right.$ and $\mathrm{S} / \mathrm{D}=2)$ 


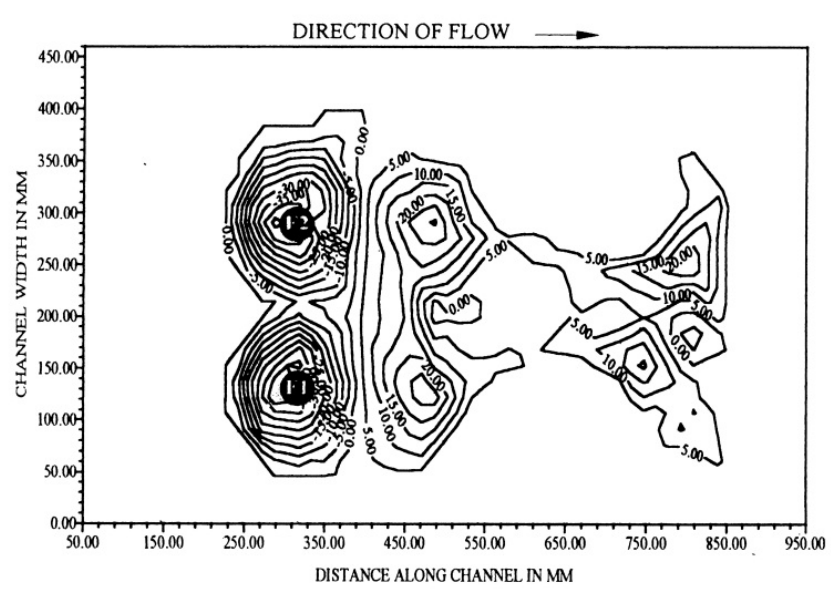

Fig -13: Scour hole due to unidirectional flow for two piers in a side by side arrangement $\left(D=32 \mathrm{~mm}, Y_{0}=160 \mathrm{~mm}\right.$ and

$$
\mathrm{S} / \mathrm{D}=5)
$$

\section{CONCLUSIONS}

This paper presents the results of an experimental study of scour around single pile and two piers with side by side arrangement. Different water depths, pier diameters and pier spacing on the development of the potential scour hole have been investigated. The conclusions drawn from the present study can be summarized as follows: Comparison with a single, horseshoe vortex caused the scouring to be more in side by side arrangement piers. The magnitude and extent of the scour depth depends directly on pier size, pier spacing and flow condition. Piers, which are larger in diameter, produced greater scour depth. The two piers act as an obstruction which disturbed the flow field and caused large turbulence levels to be generated. Thus, a further increase in the scouring velocity is produced giving relatively higher scour depth values.

\section{ACKNOWLEDGEMENTS}

The authors would like to thank and express a sincere appreciation to all parties especially to the Hydraulic and Hydrology Laboratory, Faculty of Civil Engineering, Universiti Teknologi Malaysia (UTM) technical staff who have been involved for implementing this research.

\section{REFERENCES}

[1]. Kothyari, U. C., Rangaraju, K. G. and Garde, R. J., "Temporal Variation of Scour around Circular Bridge Piers". Journal of Hydraulic Engineering, ASCE, 118: 1091-1106, Aug. 1992a.

[2]. Breusers, H. N. C. and Raudkivi, A. J., "Scouring". IAHR Hydraulic Design Manual 2, Balkema Rotterdam, The Netherlands. 1991.
[3]. Melville, B. W. and Chiew, Y. M., "Time Scale for Local Scour at Bridge Piers". Journal of Hydraulic Engineering, ASCE, 125(1): 59-65, 1999.

[4]. Melville, B. W. and Coleman, S. E., "Bridge Scour". Water Resources publications LLC, Colirado, USA. 2000.

[5]. Cheremisioff, P. N., "Civil Enginering Practice". Technomics Publishing Company. Volume 2, 1988.

[6]. Mubeen Beg, "Characteristics of Developing Scour Holes around Two Piers Placed in Transverse Arrangement". International Conference on Scour and Erosion (ICSE-5), ASCE, 76-85, 2010.

[7]. Graf W. H. and Istiarto, I., "Flow Pattern in The Scour Hole around A Cylinder". Journal of Hydraulic Research, 40(1): 13-20, 2002.

[8]. Ahmed, F. and Rajaratnam, N., "Flow around Bridge Piers". Journal of Hydraulic Engineering, 124(3): 288-300, 1998.

[9]. Ettema, R., Kirkil, G. and Muste, M., "Similitude of Large Scale Turbulence in Experiments on Local Scour at Cylinders". Journal of Hydraulic Engineering 132(1): 33-40, 2006.

[10]. Mohammed, T. A., MegatMohd Noor, M. J., Ghazali, A.H., Yusuf, B. and Saed, K., "Physical Modeling of Local Scouring around Bridge Piers in Erodable Bed”. Journal of King Saud University, Engineering Science 19(2): 195-207, 2007.

[11]. Kirkil, G., Constantinescu, S. G. and Ettema, R., "Coherent Structures in The Flow Field around A Circular Cylinder with Scour Hole". Journal of Hydraulic Engineering 134(5): 572-587, 2008.

[12]. Padmini, K. and Asis, M., "Local Scour around Hydraulic Structures". International Journal of Recent Trends in Engineering 1(6): 59-61, May. 2009.

[13]. Yasser E. M. and Ahmed, F. A., "Scour around Single Pile and Pile Groups Subjected to Waves and Currents". International Journal of Engineering Science and Technology (IJEST) 3(11): 8160-8178, November. 2011.

[14]. Guney, M. S., Aksoy, A. O. and Bombar, G., "Experimental Study of Local Scour versus Time around Circular Bridge Pier". 6th International Advanced Technologies Synposium (IATS'11), Elazig, Turkey. 135-137, May. 2011.

[15]. Elsebaie I. H., "An Experimental Study of Local Scour around Circular Bridge Pier in Sand Soil". Inetrnational Journal of Civil and Environmental Engineering 13(1): 23-28, February. 2013.

[16]. Ataie-Ashtiani, B. and Beheshti, A. A. "Experimental Investigation of Clear-water Local Scour at Pile Groups". Journal of Hydraulic Engineering132(10): 1100-1104, 2006. 
[17]. Coleman, S. E., "Clearwater Local Scour at Complex Piers". Journal of Hydraulic Engineering 131(4):330334, 2005.

[18]. Ataie-Ashtiani, B. and Baratian-Ghorghi, Z. and Beheshti, A. A.,"Experimental Investigation of Clear-water Local Scour of Compound Piers". Journal of Hydraulic Engineering 136(6): 343-351, 2010.

[19]. Ataie-Ashtiani, B. and Aslani-Koordkandi, A., "Flow Field around Single and Tandem Piers". Flow Turbulence Combust 90: 471-490, 2013.

[20]. Salim, M. and Jones, J. S., "Scour around Exposed Pile Foundations". Compilation of Conference Scour Papers (1991-1998), ASCE, 1998.

[21]. Ataie-Ashtiani, B. and Aslani-Koordkandi, A., "Floe Field around Side-by-Side Piers with and without a Scour Hole". European Journal of Mechanics B/Fluids 36: 152-166, 2012.

[22]. Hannah, C. R., "Scour at Pile Groups". University of Canterbury, New Zealand. Civil Engineering Research Report No. 78-3, 92, 1978.

[23]. Babaeyan-Koopaei, K. and Valentine, E. M., "Bridge Pier Scour in Self-Formed Laboratory Channels". IAHR Congress, 22-27, 1999.

[24]. Akilli, H., Akar, A. and Karakus, C., "Flow Characteristics of Circular Cylinders Arranged Sideby-Side in Shallow Water". Flow Measurement Instrumentation 15: 187-189, 2004.

[25]. Singh, S. M. and Maiti, P. R., "Local Scouring around a Circular Pier in Open Channel". International Journal of Emerging Technology and Advanced Engineering 2(5): 454-458, 2012.

[26]. Movahedi, N., Dehghani, A. A., Arabi, M. J. and Zahiri, A. R., "Temporal Evaluation of Local Scour Depth around Side-by-side Piers". Journal of Civil Engineering and Urbanism 3(3): 82-86, 2013.

\section{BIOGRAPHIES}

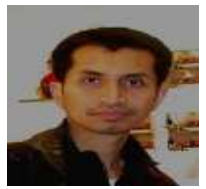

Zulhilmi Ismail - Currently, he is a senior lecturer in the Department of Hydraulics and Hydrology, UTM since 2008.

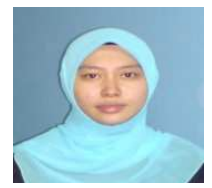

MazlinJumian - Currently, she is aPh.D student at UniversitiTeknologi Malaysia (UTM).

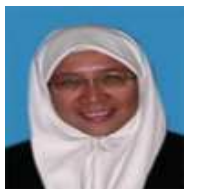

FaridahJaafarSidek - Currently, she is anassociate professor in the Department of Hydraulics and Hydrology. She is a member of Coastal and Offshore Engineering Institute (COEI) at UTM Kuala Lumpur.

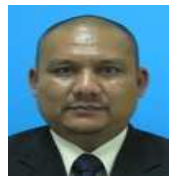

Ahmad KhairiAbdWahab - Currently, he is a professor in the Department of Hydraulics and Hydrology. He is a Director of Coastal and Offshore Engineering Institute (COEI) at UTM Kuala Lumpur.

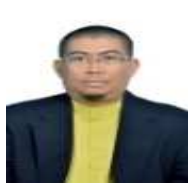

Zulkiflee Ibrahim - Currently, he is a senior lecturer in the Department of Hydraulics and Hydrology, UTM since 1993.

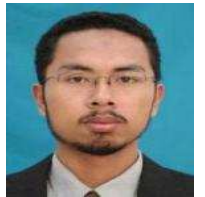

MohamadHidayat Jamal - Currently, he is a senior lecturer in the Department of Hydraulics and Hydrology, UTM since 2002.He is a member of Coastal and Offshore Engineering Institute (COEI). 